\title{
POTENSI TANAMAN HIAS DALAM MEREMEDIASI TANAH TERCEMAR LOGAM MERKURI (Hg) (STUDI KASUS : TAILING MANDOR)
}

\author{
Rizka Ulimma ${ }^{1)}$,Isna Apriani ${ }^{1)}$,Sarma Siahaan ${ }^{2)}$ \\ 1) Program Studi Teknik Lingkungan, Universitas Tanjungpura, Pontianak \\ ${ }^{2)}$ Program Studi Teknologi Hasil Hutan,Universitas Tanjungpura, Pontianak \\ Email : ulimmarizka@gmail.com
}

\begin{abstract}
ABSTRAK
Aktivitas penambangan emas tanpa izin di Mandor telah lama ditinggalkan selama 10 tahun dan menghasilkan limbah tanah (tailing) berpotensi merusak lingkungan yaitu limbah merkuri yang berasal dari proses amalgamasi. Logam berat dalam tanah sangat sulit untuk diuraikan dan memerlukan biaya yang besar untuk memulihkannya. Metode yang efektif dan efisien dapat digunakan yaitu fitoremediasi. Penelitian ini menggunakan kemampuan tanaman hias hanjuang (Cordyline fruicosa), helikonia (Heliconia psittacorum) dan lidah mertua (Sansevieria trifasciata) untuk mengurangi cemaran logam merkuri $(\mathrm{Hg})$ dalam tanah. Penelitian dilakukan selama 2 bulan dengan komposisi media tanam yang digunakan adalah tanah biasa tanpa tailing (kontrol), tanah tailing, tailing dan kompos kemudian dianalisis kandungan logam merkuri $(\mathrm{Hg})$ tanaman dengan metode analisa AAS (Atomic Absorption Spectrophotometric). Tujuan penelitian ini adalah efisiensi penyerapan merkuri $(\mathrm{Hg})$ dan besarnya nilai BCF dan TF dari tanaman hias. Berdasarkan hasil penelitian nilai efisiensi penyerapan pada tanaman hias hanjuang (Cordyline fruicosa) sebesar 29,03\%, helikonia (Heliconia psittacorum) sebesar 42,98\% dan lidah mertua (Sansevieria trifasciata) sebesar $57,36 \%$ terdapat di media campuran tailing dan kompos sedangkan di media tailing yaitu $25,30 \% ; 35,71 \% ; 46,72 \%$. Nilai bioconcentration factor (BCF) yang dihasilkan oleh tanaman hanjuang (Cordyline fruicosa) sebesar 0,290, helikonia (Heliconia psittacorum) sebesar 0,378 dan lidah mertua (Sansevieria trifasciata) sebesar 0,463 terdapat di media campuran dan media tailing sebesar 0,$235 ; 0,319 ; 0,400$. Nilai translocation factor (TF) di media campuran oleh tanaman hanjuang (Cordyline fruicosa) sebesar 0, helikonia (Heliconia psittacorum) sebesar 0,106 dan lidah mertua (Sansevieria trifasciata) sebesar 0,241 dan media tailing sebesar 0,051;0,202 ; 0,157 . Nilai TF dan BCF menunjukkan ketiga tanaman hias ini termasuk dalam akumulator sedang dan proses remediasi adalah fitostabilisasi.
\end{abstract}

Kata Kunci : Mandor, Fitoremediasi, Logam Merkuri (Hg), Tanaman Hias

\section{ABSTRACT}

Illegal gold mining activities in Mandor had long been abandoned for 10 years and produce waste soil (tailings) are potentially damaging to the environment is waste mercury from the amalgamation process. Heavy metals in the soil is very difficult tounravel and require cost of money to restore it. The method that can be used effectively and efficiently, is phytoremediation. This research uses the ability hanjuang ornamental plant (Cordyline fruicosa), heliconias plant (Heliconia psittacorum) and the tongue-in-law plant(Sansevieria trifasciata) to reduce metal contamination of mercury $(\mathrm{Hg})$ in the soil. Research carried out for 2 months with the composition of the planting medium used is ordinary soil without tailings (control), tailings or contaminated soil, tailings and compost (mixed media). After 2 months to analyze the content of mercury $(\mathrm{Hg})$ in plants with analytical methods AAS (Atomic Absorption Spectrophotometric). The aim of this research is the mercury absorption efficiency $(\mathrm{Hg})$ and the value of BCF and TF of the ornamental plants. The research showed the efficiency of absorption hanjuang ornamental plant (Cordyline fruicosa) amounted to 29,03\%, heliconias plant (Heliconia psittacorum) amounted to 42,98\%, and the tongue-in-law plant (Sansevieria trifasciata) amounted to $57,36 \%$ in the tailings and mixed media whereas compost in the contaminated soil is $25.30 \% ; 35.71 \% ; 46.72 \%$. The Bioconcentration Factor (BCF) is generated by hanjuang plant (Cordyline fruicosa) amounted to 0.290, heliconias plant (Heliconia psittacorum) amounted to 0,378 and the tongue-in-law plant (Sansevieria trifasciata) amounted to 0,463 contained in mixed media and contamined soil amounted to $0.051 ; 0.202 ; 0.157$. BCF and TF values shows that the three plants were included in accumulator and the remediation process is fitostabilisasi.

Keywords: Mandor, Phytoremediation, Mercury ( $\mathrm{Hg})$, ornamental plants 


\section{PENDAHULUAN}

Kecamatan Mandor berada di wilayah Kabupaten Landak Kalimantan Barat. Wilayah Kabupaten Landak memiliki 26 titik lokasi penambangan emas termasuk Kecamatan Mandor dengan luas 3.782 ha. Penambangan emas di Mandor merupakan kegiatan illegal yang secara tradisional dilakukan sebagian besar masyarakat atau penduduk setempat. Penambangan tersebut menggunakan merkuri sebagai proses pengolahannya dan merupakan bahan untuk mengikat dan pemisah bijih emas dengan pasir, lumpur dan air. Kegiatan penambangan emas ini sudah berlangsung lama ditinggalkan hampir 10 tahun hingga sekarang masih tersebar di desa-desa. Berdasarkan hasil analisis pengujian yang telah dilakukan bahwa tailing yang berada di areal Mandor memiliki kandungan merkuri yang melebihi batas baku yaitu $0,6 \mathrm{mg} / \mathrm{kg}$. Standar baku mutu kelimpahan logam berat merkuri $(\mathrm{Hg})$ dalam tanah yaitu $0,03 \mathrm{ppm}$ atau $0,03 \mathrm{mg} / \mathrm{kg}$ dan konsentrasi kritis 0,3-0,5 ppm (Alloway, 1995).

Mengingat sifat merkuri yang sangat berbahaya bagi lingkungan, maka perlu dilakukan suatu upaya perbaikan lingkungan agar tidak terjadi kerusakan yang dapat memperparah kondisi menjadi lebih buruk. Upaya yang dapat dilakukan dengan penerapan metode fitoremediasi. Fitoremediasi merupakan proses penurunan kadar polutan tanah dengan menggunakan tanaman sebagai indikator dalam menemukan polutan. Beberapa hasil penelitian yang telah dilakukan bahwa ketiga tanaman hias hanjuang (Cordyline fruicosa), helikonia (Heliconia psittacorum) dan lidah mertua (Sansevieria trifasciata) mampu meremdiasi logam berat yang ada di dalam tanah namun potensi dari tanaman hias tersebut belum dapat diketahui seberapa toleransi terhadap logam merkuri $(\mathrm{Hg})$.

\section{METODOLOGI PENELITIAN}

\section{A. Tempat dan Waktu Pengambilan Sampel}

Pengambilan sampel tailing dilakukan di areal pertambangan emas Kecamatan Mandor, Kabupaten Landak Kalimantan Barat. Analisis logam berat merkuri ( $\mathrm{Hg})$ dalam tanah dan kadar merkuri $(\mathrm{Hg})$ pada tanaman dilakukan di Balai Riset Standarisasi Industri (BARISTAN) Pontianak.

\section{B. Prosedur Penelitian}

Pada penelitian ini metode yang digunakan adalah observasi dan eksperimental. Penelitian observasi adalah pengumpulan data berupa gambaran atau uraian keadaan lokasi eksisting. Penelitian eksperimental adalah melakukan penelitian dalam skala laboratorium.

\section{- Pengambilan Sampel Tailing di Mandor Kalimantan Barat \\ - Persiapan Lapangan}

Menetapkan titik koordinat di lokasi secara akurat menggunakan alat GPS. Metode yang digunakan penelitian lapangan ini yaitu metode purposive. Metode ini bertujuan untuk menetapkan titik pengambilan sampel yang dipilih secara relevan mewakili areal dari buangan air limbah tailing.

\section{- Pengambilan dan Perlakuan Sampel}

Pengambilan sampel tailing diambil di dekat sumber proses pencucian (hulu) pada titik pertama dengan jarak \pm 25 meter dari limbah pencucian dapat dilihat dari Gambar 1. Pengambilan sampel di titik kedua (tengah) yang berjarak 140 meter dari titik pengambilan sampel yang pertama. Titik pengambilan sampel kedua merupakan aliran air limbah yang mengalir sampai di titik akhir pembuangan limbah (hilir). Pengambilan sampel di hilir berjarak 122 meter dari titik pengambilan sampel kedua.Pengambilan sampel dilakukan pada kedalaman 0-15 cm. Sampel dari ketiga titik tersebut kemudian 
dihomogenkan dan dianalisis parameter meliputi $\mathrm{pH}$, C-organik, merkuri $(\mathrm{Hg})$ dan tekstur tanah.

Persiapan percampuran sampel tailing dan pupuk kompos dengan perbandingan 1:1 untuk komposisi tailing dan pupuk kompos masing - masing sebanyak $15 \mathrm{~kg}$ kemudian diinkubasi selama 1 bulan bertujuan menghomogenkan campuran tersebut serta mengetahui pengaruh kompos terhadap tailing. Setelah 1 bulan campuran tailing dan kompos dianalisis $\mathrm{pH}, \mathrm{C}$-organik dan merkuri $(\mathrm{Hg})$.

- Penanaman dan Pengamatan

Tanaman hias yang telah dipersiapkan yaitu hanjuang (Cordyline fruicosa), helikonia (Heliconia psittacorum) dan lidah mertua (Sansevieria trifasciata) berumur 5 bulan dengan spesifikasi tinggi tanaman sebesar $30-40 \mathrm{~cm}$. Tanaman hias tersebut akan ditanam didalam polybag yang telah disiapkan, yaitu P0 (tanah kontrol), P1 (tailing tanpa kompos) dan P2 (2,5 kg tailing dan 2,5 kg kompos/polybag). Masing - masing setiap perlakuan dilakukan sebanyak 3 ulangan. Tanaman yang telah ditanam pada polybag diamati selama 2 bulan.

Setelah 2 bulan tanaman dipanen, sampel tanaman tersebut dipisahkan antara bagian tajuk dan akarnya kemudian dikemas serta diberi label pengkodean. Sampel siap dipreparasi dan dilakukan pengukuran merkuri dengan AAS (Atomic Absorption Spectrophotometric) yaitu dengan alat HVG-1 AAS. Analisis kadar merkuri (Hg) dalam tanah (tailing) dan tanaman berdasarkan SNI 06-6992.2-2004.

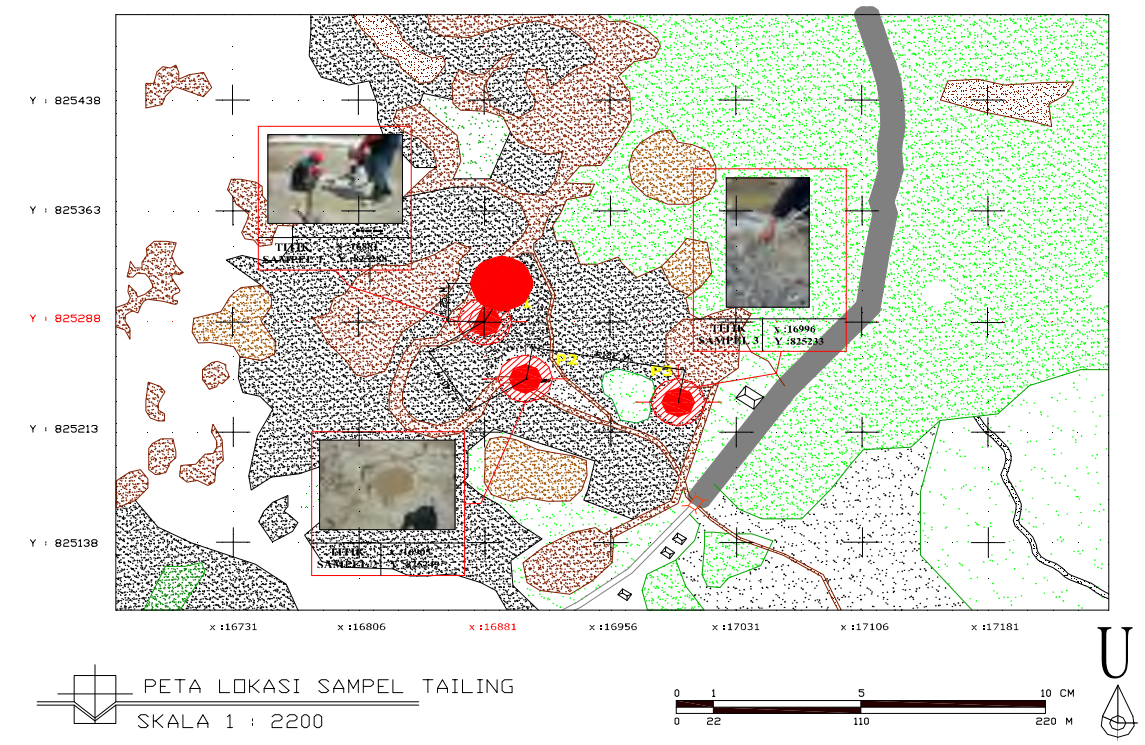

Gambar 1. Peta Lokasi Pengambilan Sampel Tailing

\section{Analisa Data}

Data yang diperoleh dari penelitian yang telah dilakukan akan dianalisa sebagai berikut :

A. Efisiensi penyerapan logam $\mathrm{Hg}$ pada tanaman didasarkan pada konsentrasi logam merkuri $(\mathrm{Hg})$ dalam tanaman serta konsentrasi logam merkuri $(\mathrm{Hg})$ dalam media tanah (Haryanti dkk. 2013).

$$
\text { Efisiensi Penyerapan }=\frac{\text { Logam berat pada tanaman }}{\text { Logam berat pada tailing }(\text { awal })} \times 100 \%
$$


B. Potensi tanaman dalam mengakumulasi merkuri $(\mathrm{Hg})$ pada tanah tailing akan dianalisa dengan menghitung nilai BCF ditentukan oleh rasio logam di akar dengan yang terdapat di dalam tanah (Ghosh and Singh, 2013).

$$
B C F=\frac{\text { Konsentrasi logam dalam tajuk atau akar tumbuhan }}{\text { Konsentrasi logam dalam tanah }}
$$

C. Proses terjadinya translokasi perbandingan antara konsentrasi logam di tajuk dengan konsentrasi logam di akar pada tanaman ditentukan dengan nilai TF (Haque et. al. 2008).

$$
T F=\frac{\text { Konsentrasi logam dalam tajuk tumbuhan }}{\text { Konsentrasi logam dalam akar tumbuhan }}
$$

\section{HASIL DAN PEMBAHASAN}

\section{A. Analisis Pendahuluan}

Analisis pendahuluan dilakukan untuk mengetahui karakteristik tanah yang akan digunakan pada penelitian ini. Tanah yang dianalisa adalah tanah tailing yang merupakan tanah dari sisa (ampas) pengolahan tambang emas yang mengandung merkuri.

Tabel 1. Hasil Analisis Tanah Tailing

\begin{tabular}{clcc}
\hline No. & Parameter Uji & Satuan & Hasil Uji \\
\hline 1. & pH H $\mathrm{H}_{2} \mathrm{O}$ & - & 6,27 \\
2. & $\mathrm{C}-$ Organik & $\%$ & 0,269 \\
3. & Merkuri $(\mathrm{Hg})$ & $\mathrm{mg} / \mathrm{kg}$ & 0,548 \\
4. & Tekstur & $\%$ & \\
& a. Pasir & $\%$ & 98,34 \\
& b. Debu & $\%$ & 0,73 \\
& c. Liat & 0,93 \\
\hline
\end{tabular}

Sumber : Hasil Analisis Laboratorium BARISTAN, 2015

Berdasarkan pada Tabel 1. hasil anaisis menunjukkan bahwa tanah tailing memiliki $\mathrm{pH}$ yang agak asam, yaitu 6,27. Hasil pengukuran $\mathrm{pH}$ tailing mendekati netral, konsentrasi logam merkuri di tanah dapat merubah menjadi senyawa yang mengendap mengakibatkan kadar merkuri dalam tanah menjadi menurun dan kemungkinan sebagian merkuri di dalam tanah pada kondisi oksidasi dalam bentuk ion $\mathrm{Hg}^{2+}$ yang mudah larut dalam air sehingga mudahnya akar tanaman dalam menyerap merkuri di dalam tanah. Nilai $\mathrm{pH}$ tanah juga mempengaruhi pertumbuhan dan perkembangan tanaman sesuai dengan Soepardi (1983) yang menyatakan pH tanah mempengaruhi serapan unsur hara dan pertumbuhan tanaman melalui pengaruh langsungnya terhadap tersediannya unsur hara dan adanya unsur-unsur beracun.

Hasil analisis terhadap kandungan C-organik pada tanah tailing tergolong sangat rendah $(<1 \%)$ yaitu sebesar $0,269 \%$. Mirdat dkk. (2013) menyatakan bahwa kandungan bahan organik yang rendah mengakibatkan konsentrasi merkuri dalam tanah menjadi tinggi dikarenakan bahan organik tanah mampu mengikat atay menonaktifkan penyebaran merkuri dalam tanah.

Tingginya kandungan merkuri $(\mathrm{Hg})$ pada tailing dengan nilai ambang konsentrasi kritis yaitu $0,548 \mathrm{mg} / \mathrm{kg}$. Tingginya kandungan merkuri tersebut dapat disebabkan karena penggunaan merkuri dalam jumlah yang sangat besar pada proses pengolahan emas. Penggunaan merkuri untuk satu gram emas dibutuhkan 1 hingga 2 gram merkuri atau air raksa. Berdasarkan Data Dinas Pertambangan dan Energi Provinsi Kalimantan Barat (2014) produksi emas para penambang diperkirakan mencapai 8 kilogram lebih 
per hari. Artinya, pemakaian merkuri atau air raksa membutuhkan $8000 \mathrm{ml}$ per hari yang digunakan sebagai pengikat emas.

Secara fisik tailing memiliki persentase tekstur berpasir yang tinggi dengan sebaran fraksi pasir 98,34\%, debu 0,73\% dan liat 0,93\%. Menurut Hardjowigeno (1995) menyatakan bahwa tanah-tanah yang bertekstur pasir mempunyai luas permukaan yang kecil sehingga sulit untuk menyerap air dan unsur hara.

\section{B. Analisis Karakteristik Percampuran Tailing dan Pupuk Kompos}

Analisis karakteristik percampuran tailing dan pupuk kompos yang telah diinkubasi selama 1 bulan dapat dilihat pada Tabel 2. sebagai berikut :

Tabel 2. Hasil Analisa Percampuran Tailing dan Kompos

\begin{tabular}{clcc}
\hline No. & \multicolumn{1}{c}{ Parameter Uji } & Satuan & Hasil Uji \\
\hline 1. & $\mathrm{pH} \mathrm{H}_{2} \mathrm{O}$ & - & 5,39 \\
2. & $\mathrm{C}-$ Organik & $\%$ & 5,2 \\
3. & Merkuri $(\mathrm{Hg})$ & $\mathrm{mg} / \mathrm{kg}$ & 0,387 \\
\hline
\end{tabular}

Sumber : Hasil Analisis Laboratorium BARISTAN, 2015

'Berdasarkan hasil analisis menunjukkan kandungan merkuri $(\mathrm{Hg})$ di media tailing dan kompos mengalami penurunan sebesar $29 \%$. Peran kompos dalam tanah dapat bereaksi dengan logam berat membentuk senyawa kompleks (organo metalic complex) sehingga mengurangi sifat racun dari logam berat (Stevenson, 1982). Penambahan bahan organik yang belum matang atau masih mengalami proses dekomposisi dapat menyebabkan penurunan $\mathrm{pH}$ tanah karena selama proses dekomposisi akan melepaskan asam-asam organik yang menyebabkan menurunnya $\mathrm{pH}$ tanah. Pemberian kompos pada tanah tailing dapat meningkatkan kandungan hara terutama nitrogen (N) dan fosfor (P) sehingga terjadi peningkatan terhadap kandungan C-organik pada tanah tailing.

\section{Hasil Pengukuran Kadar Merkuri ( $\mathrm{Hg})$ dalam Tanaman}

\section{- Tanaman Hanjuang (Cordyline Fruicosa)}

Pengukuran terhadap kandungan merkuri pada tanaman bertujuan untuk mengetahui kemampuan tanaman hias dalam menyerap logam $\mathrm{Hg}$ yang ada di dalam tanah. Hasil pengukuran kadar merkuri pada tanaman hias hanjuang ditampilkan dalam Tabel 3. sebagai berikut.

Tabel 3. Hasil Pengukuran Kadar Merkuri pada Tanaman Hanjuang (Cordyline fruicosa)

\begin{tabular}{|c|c|c|c|c|c|c|c|}
\hline \multirow[b]{2}{*}{ No. } & \multirow[b]{2}{*}{$\begin{array}{c}\text { Kode } \\
\text { Sampel }\end{array}$} & \multirow[b]{2}{*}{$\begin{array}{c}\text { pH } \\
\text { Tanah }\end{array}$} & \multicolumn{2}{|c|}{ Kadar Hg } & \multicolumn{2}{|c|}{ Kandungan $\mathrm{Hg}(\mathrm{mg} / \mathrm{kg})$} & \multirow{2}{*}{$\begin{array}{c}\text { Efisiensi } \\
\text { Penyerapan } \\
\text { (\%) }\end{array}$} \\
\hline & & & $\begin{array}{c}\text { Tajuk } \\
\text { (mg/kg) }\end{array}$ & $\begin{array}{c}\text { Akar } \\
\text { (mg/kg) }\end{array}$ & Tanaman & $\begin{array}{l}\text { Tanah } \\
\text { (awal) }\end{array}$ & \\
\hline \multirow{9}{*}{1.} & $H(P 0)-1(01)$ & 5,5 & $<0,02$ & $<0,02$ & & & \\
\hline & $H(P 0)-4(02)$ & 5 & $<0,02$ & $<0,02$ & 0 & 0 & 0 \\
\hline & $H(P 0)-7(03)$ & 5 & $<0,02$ & $<0,02$ & & & \\
\hline & $H(P 1)-2(01)$ & 6,1 & $<0,02$ & 0,030 & & & \\
\hline & $H(P 1)-5(02)$ & 6,4 & $<0,02$ & 0,139 & 0,112 & 0,387 & 29,03 \\
\hline & $H(P 1)-8(03)$ & 6,2 & $<0,02$ & 0,168 & & & \\
\hline & $H(P 2)-3(01)$ & 5,4 & $<0,02$ & 0,060 & & & \\
\hline & $H(P 2)-6(02)$ & 5,5 & $<0,02$ & 0,129 & 0,139 & 0,548 & 25,30 \\
\hline & $H(P 2)-9(03)$ & 5,8 & 0,03 & 0,197 & & & \\
\hline
\end{tabular}

Sumber : Hasil Analisis Laboratorium BARISTAN dan analisis perhitungan, 2015

$\begin{aligned} \text { Keterangan : (01) : ulangan } 1 & \text { (P0) : Tanah tanpa tailing (kontrol) } \\ \text { (02) : ulangan 2 } & \text { (P1) : Tailing dan Kompos } \\ \text { (03) : ulangan 3 } & \text { (P2) : Tailing tanpa kompos }\end{aligned}$

Berdasarkan Tabel 3. dapat dilihat bahwa kandungan merkuri yang terakumulasi sebagian besar terdapat di bagian akar tanaman hanjuang (Cordyline fruicosa). Pada 
media campuran tailing dan kompos akumulasi logam Hg yang tertinggi pada ulangan (03) sebesar 0,168 mg/kg, namun kadar $\mathrm{Hg}$ yang diserap belum mencapai pada bagian tajuk tanaman. Begitupula, pada ulangan (01) dan (02) akumulasi logam $\mathrm{Hg}$ hanya terjadi pada bagian akar tanaman. Media tailing akumulasi logam $\mathrm{Hg}$ tertinggi terjadi pada ulangan (03) sebesar $0,197 \mathrm{mg} / \mathrm{kg}$ dan mampu mentranslokasikannya di bagian tajuknya sebesar $0,03 \mathrm{mg} / \mathrm{kg}$. Besarnya penyerapan logam merkuri di bagian akar tanaman daripada tajuk dikarenakan akar merupakan organ tanaman yang berkontak langsung dengan media tanam.

\section{- Tanaman Helikonia (Heliconia Psittacorum)}

Pengukuran kadar merkuri pada tanaman hias helikonia dapat dilihat Tabel 4. sebagai berikut.

Tabel 4. Hasil Pengukuran Kadar Merkuri pada Tanaman Helikonia (Heliconia Psittacorum)

\begin{tabular}{|c|c|c|c|c|c|c|c|}
\hline \multirow[b]{2}{*}{ No. } & \multirow{2}{*}{$\begin{array}{l}\text { Kode } \\
\text { Sampel }\end{array}$} & \multirow{2}{*}{$\begin{array}{c}\text { pH } \\
\text { Tanah }\end{array}$} & \multicolumn{2}{|c|}{ Kadar Hg } & \multicolumn{2}{|c|}{ Kandungan $\mathrm{Hg}$ (mg/kg) } & \multirow{2}{*}{$\begin{array}{c}\text { Efisiensi } \\
\text { Penyerapan (\%) }\end{array}$} \\
\hline & & & $\begin{array}{c}\text { Tajuk } \\
\text { (mg/kg) }\end{array}$ & $\begin{array}{c}\text { Akar } \\
\text { (mg/kg) }\end{array}$ & Tanaman & $\begin{array}{l}\text { Tanah } \\
\text { (awal) }\end{array}$ & \\
\hline \multirow{9}{*}{2.} & $\mathrm{HE}(\mathrm{P0})-1(01)$ & 5,4 & $<0,02$ & $<0,02$ & & & \\
\hline & $\mathrm{HE}(\mathrm{PO})-4(02)$ & 4,9 & $<0,02$ & $<0,02$ & 0 & 0 & 0 \\
\hline & $\mathrm{HE}(\mathrm{PO})-7(03)$ & 4,8 & $<0,02$ & $<0,02$ & & & \\
\hline & $\mathrm{HE}(\mathrm{P} 1)-2(01)$ & 6,7 & $<0,02$ & 0,150 & & & \\
\hline & $\mathrm{HE}(\mathrm{P} 1)-5(02)$ & 6,1 & $<0,02$ & 0,100 & 0,166 & 0,387 & 42,98 \\
\hline & $\mathrm{HE}(\mathrm{P} 1)-8(03)$ & 6,3 & 0,060 & 0,189 & & & \\
\hline & $\mathrm{HE}(\mathrm{P} 2)-3(01)$ & 5,5 & $<0,02$ & 0,209 & & & \\
\hline & $\mathrm{HE}(\mathrm{P} 2)-6(02)$ & 5,5 & 0,060 & 0,100 & 0,196 & 0,548 & 35,71 \\
\hline & $\mathrm{HE}(\mathrm{P} 2)-9(03)$ & 5,7 & $<0,02$ & 0,218 & & & \\
\hline
\end{tabular}

Sumber : Hasil Analisis Laboratorium BARISTAN dan analisis perhitungan, 2015

$$
\begin{aligned}
& \text { Keterangan : (01) : ulangan } 1 \quad \text { (P0) : Tanah tanpa tailing (kontrol) } \\
& \text { (02) : ulangan } 2 \quad \text { (P1) : Tailing dan Kompos } \\
& \begin{array}{ll}
\text { (03) : ulangan } 3 & \text { (P2) : Tailing tanpa kompos }
\end{array}
\end{aligned}
$$

Berdasarkan hasil pengukuran konsentrasi merkuri yang terserap oleh tanaman helikonia di media campuran terjadi pada ulangan (03) dengan konsentrasi tertinggi sebesar $0,189 \mathrm{mg} / \mathrm{kg}$ dan $0,060 \mathrm{mg} / \mathrm{kg}$ di bagian tajuknya. Sedangkan pada media tailing akumulasi logam merkuri $(\mathrm{Hg})$ yang terjadi cukup tinggi di bagian akar tanaman. Pada ulangan (01) dan (03) akumulasi merkuri yang terjadi cukup besar daripada ulangan (02) namun akumulasi tersebut belum mencapai bagian tajuk tanaman. Pada ulangan (02) akumulasi logam merkuri $(\mathrm{Hg})$ terjadi sampai pada bagian tajuk tanaman dengan konsentrasi sebesar $0,060 \mathrm{mg} / \mathrm{kg}$.

- Tanaman Lidah Mertua (Sansevieria trifasciata)

Pengukuran kadar merkuri pada tanaman hias lidah mertua (Sansevieria trifasciata) dapat dilihat pada Tabel 5. sebagai berikut.

\begin{tabular}{|c|c|c|c|c|c|c|c|}
\hline \multirow[b]{2}{*}{ No. } & \multirow[b]{2}{*}{$\begin{array}{l}\text { Kode } \\
\text { Sampel }\end{array}$} & \multirow[b]{2}{*}{$\begin{array}{c}\mathrm{pH} \\
\text { Tanah }\end{array}$} & \multicolumn{2}{|c|}{ Kadar Hg } & \multicolumn{2}{|c|}{ Kandungan $\mathrm{Hg}$ (mg/kg) } & \multirow{2}{*}{$\begin{array}{c}\text { Efisiensi } \\
\text { Penyerapan } \\
(\%) \\
\end{array}$} \\
\hline & & & $\begin{array}{c}\text { Tajuk } \\
\text { (mg/kg) }\end{array}$ & $\begin{array}{c}\text { Akar } \\
(\mathrm{mg} / \mathrm{kg})\end{array}$ & Tanaman & $\begin{array}{l}\text { Tanah } \\
\text { (awal) }\end{array}$ & \\
\hline \multirow{6}{*}{3.} & $\mathrm{LM}(\mathrm{D})-1(\mathrm{~K})(01)$ & 4,5 & $<0,02$ & $<0,02$ & & & \\
\hline & $\mathrm{LM}(\mathrm{D})-4(\mathrm{~K})(02)$ & 4,8 & $<0,02$ & $<0,02$ & 0 & 0 & 0 \\
\hline & LM(D) - 7(K) (03) & 4,7 & $<0,02$ & $<0,02$ & & & \\
\hline & $\mathrm{LM}(D)-2(C)(01)$ & 6,2 & 0,069 & 0,210 & & & \\
\hline & $\operatorname{LM}(D)-5(C)(02)$ & 5,9 & 0,020 & 0,188 & 0,222 & 0,387 & 57,36 \\
\hline & LM(D) - 8(C) (03) & 6,8 & 0,040 & 0,139 & & & \\
\hline
\end{tabular}

Tabel 5. Hasil Pengukuran Kadar Merkuri pada Tanaman Lidah Mertua (Sansevieria trifasciata) 


\begin{tabular}{|c|c|c|c|c|c|c|}
\hline $\operatorname{LM}(D)-3(T)(01)$ & 5,4 & $<0,02$ & 0,190 & & & \\
\hline LM(D) - 6(T) (02) & 5,2 & 0,060 & 0,259 & 0,256 & 0,548 & 46,72 \\
\hline LM(D) - 9(T) (03) & 5,6 & 0,050 & 0,209 & & & \\
\hline
\end{tabular}

Sumber : Hasil Analisis Laboratorium BARISTAN dan analisis perhitungan, 2015

Keterangan: (01) : ulangan $1 \quad$ (P0): Tanah tanpa tailing (kontrol)

(02) : ulangan $2 \quad$ (P1) : Tailing dan Kompos

(03) : ulangan $3 \quad$ (P2) : Tailing tanpa kompos

Berdasarkan pada Tabel 5. dapat dilihat bahwa serapan akumulasi logam merkuri $(\mathrm{Hg})$ pada tanaman lidah mertua (Sansevieria trifasciata) lebih besar dibandingkan dengan kedua jenis tanaman lainnya. Akumulasi logam $\mathrm{Hg}$ pada tanaman lidah mertua terjadi pada 2 bagian yaitu akar dan tajuk tanaman dengan tingkat konsentrasi merkuri yang tinggi. Pada media campuran, akumulasi logam merkuri tertinggi terjadi pada ulangan (01) yang memiliki penyerapan merkuri di bagian akar sebesar $0,210 \mathrm{mg} / \mathrm{kg}$ dan $0,069 \mathrm{mg} / \mathrm{kg}$ di tajuknya. Media tailing yang dicampur dengan kompos merupakan media yang mampu memberikan respons terhadap pertumbuhan tanaman lidah mertua (Sansevieria trifasciata) yang lebih baik.

Hasil pengukuran kadar merkuri di media tailing oleh tanaman lidah mertua (Sansevieria trifasciata), akumulasi logam merkuri $(\mathrm{Hg})$ tertinggi terjadi pada ulangan (02) sebesar 0,259 mg/kg di akar dan 0,060 mg/kg di tajuk tanaman. Pada ulangan (03) penyerapan merkuri yang diserap oleh tanaman lidah mertua (Sansevieria trifasciata) juga cukup tinggi dengan konsentrasi $0,209 \mathrm{mg} / \mathrm{kg}$ pada akar dan 0,050 mg/kg di tajuk.

\section{Efisiensi Penyerapan pada Tanaman Hias}

Efisiensi penyerapan menunjukkan besarnya nilai persentase penyerapan merkuri pada tanaman. Nilai persentase efisiensi ini dihitung dengan menjumlahkan kadar logam merkuri $(\mathrm{Hg})$ pada tanaman kemudian dirata - ratakan. Hasil rata-rata tersebut merupakan kadar total logam $\mathrm{Hg}$ dalam tanaman kemudian dibagi dengan kadar merkuri di tanah yaitu $0,387 \mathrm{mg} / \mathrm{kg}$ untuk media campuran dan media tailing kadar merkuri di tanah yaitu $0,548 \mathrm{mg} / \mathrm{kg}$. Berdasarkan hasil perhitungan menunjukkan nilai persentase dari tanaman hias hanjuang (Cordyline fruicosa), helikonia (Heliconia psittacorum) dan lidah mertua (Sansevieria trifasciata) bervariasi, efisiensi penyerapan yang lebih baik terjadi di media campuran tailing dan kompos. Hasil persentase efisiensi penyerapan pada tanaman hias tersebut dapat ditampilkan dalam grafik sebagai berikut.

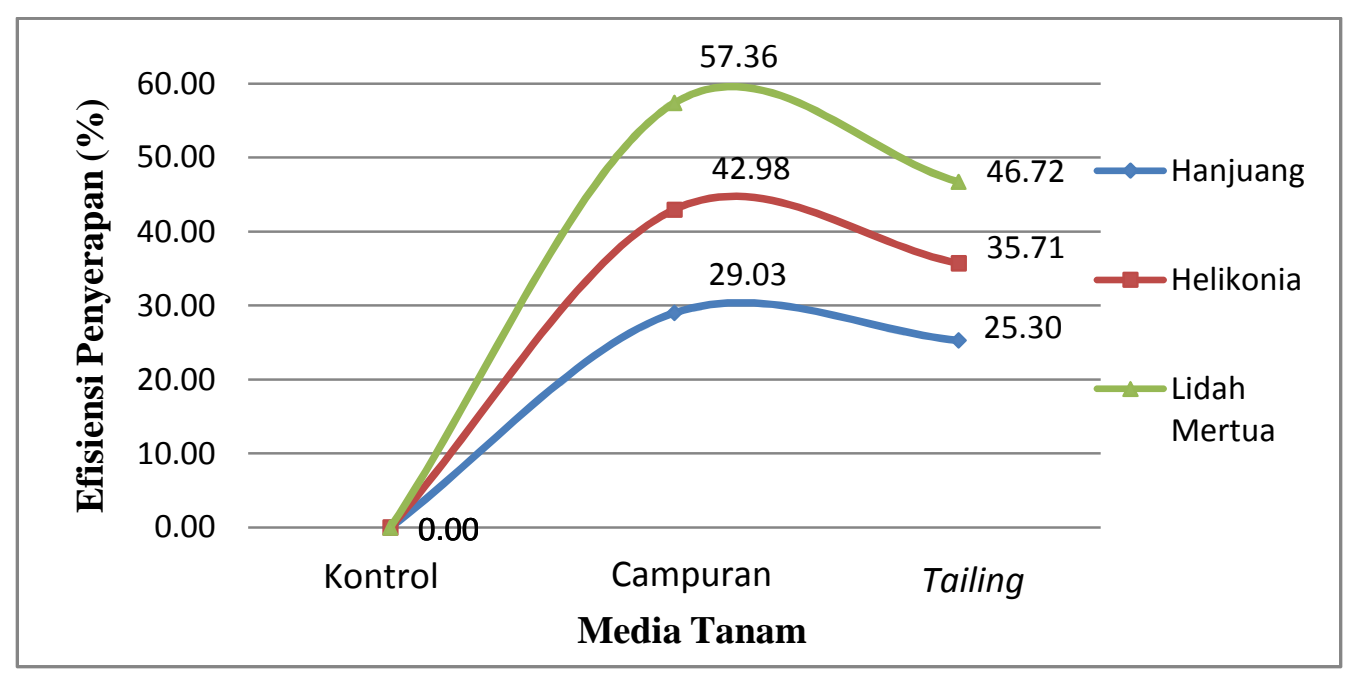

Gambar 2. Efisiensi Penyerapan pada Tanaman Hias 
Berdasarkan pada Gambar 2. menunjukkan bahwa kemampuan tanaman dalam menyerap logam merkuri bervariasi tergantung dengan jenis tanaman. Nilai efisiensi pada media tailing dan media campuran diperoleh dari tingkat konsentrasi yang berbeda. Sehingga nilai tersebut, efisiensi penyerapan merkuri yang terbaik oleh tanaman lidah mertua (Sansevieria trifasciata) di media tercemar tailing dengan nilai sebesar $46,72 \%$. Hal ini dengan pertimbangan bahwa tanaman lidah mertua (Sansevieria trifasciata) mampu hidup dan menyerap di konsentrasi tinggi.

\section{E. Analisis dan Perhitungan Nilai Bioconcentration Factor (BCF) dan Translocation Factor (TF)}

Kemampuan suatu jenis tanaman dalam mengakumulasi logam dari dalam tanah dapat dihitung dari nilai BCF dan TF. Hasil konsentrasi Hg dalam tajuk dan akar, nilai TF dan BCF pada tanaman hanjuang (Cordyline fruicosa), helikonia (Heliconia psittacorum) dan lidah mertua (Sansevieria trifasciata) dapat dilihat Tabel 6. sebagai berikut.

Tabel 6. Hasil Konsentrasi Hg dalam Tajuk dan Akar, Nilai TF dan BCF pada Tanaman Hanjuang (Cordyline fruicosa), Helikonia (Heliconia psittacorum) dan Lidah Mertua (Sansevieria trifasciata)

\begin{tabular}{|c|c|c|c|c|c|c|c|c|}
\hline No. & $\begin{array}{c}\text { Jenis } \\
\text { Tanaman } \\
\text { Hias }\end{array}$ & $\begin{array}{l}\text { Kode } \\
\text { Sampel }\end{array}$ & Perlakun & $\begin{array}{l}\text { Tajuk } \\
\text { (mg/k) }\end{array}$ & $\begin{array}{c}\text { Akar } \\
\text { (mg/k) }\end{array}$ & $\begin{array}{c}\mathrm{Hg} \\
\text { tersedia } \\
(\mathrm{mg} / \mathrm{kg})\end{array}$ & TF & $\mathrm{BCF}$ \\
\hline \multirow{10}{*}{1.} & \multirow{10}{*}{ Hanjuang } & \multicolumn{2}{|c|}{ Campuran } & & & & & \\
\hline & & $\mathrm{H}-2(\mathrm{C})$ & 1 & 0 & 0,030 & 0,387 & 0 & 0,078 \\
\hline & & $H-5(C)$ & 2 & 0 & 0,139 & 0,387 & 0 & 0,359 \\
\hline & & $\mathrm{H}-8(\mathrm{C})$ & 3 & 0 & 0,168 & 0,387 & 0 & 0,434 \\
\hline & & \multicolumn{2}{|c|}{ Rata - Rata } & & & & 0 & 0,290 \\
\hline & & \multicolumn{2}{|c|}{ Tailing } & & & & & \\
\hline & & $\mathrm{H}-3(\mathrm{~T})$ & 1 & 0 & 0,060 & 0,548 & 0 & 0,109 \\
\hline & & $\mathrm{H}-6(\mathrm{~T})$ & 2 & 0 & 0,129 & 0,548 & 0 & 0,235 \\
\hline & & $\mathrm{H}-9(\mathrm{~T})$ & 3 & 0,030 & 0,197 & 0,548 & 0,152 & 0,359 \\
\hline & & Rat & Rata & & & & 0,051 & 0,235 \\
\hline \multirow{10}{*}{2.} & \multirow{10}{*}{ Helikonia } & \multicolumn{2}{|c|}{ Campuran } & & & & & \\
\hline & & $\mathrm{HE}-2(\mathrm{C})$ & 1 & 0 & 0,150 & 0,387 & 0 & 0,388 \\
\hline & & $\mathrm{HE}-5(\mathrm{C})$ & 2 & 0 & 0,100 & 0,387 & 0 & 0,258 \\
\hline & & $\mathrm{HE}-8(\mathrm{C})$ & 3 & 0,060 & 0,189 & 0,387 & 0,317 & 0,488 \\
\hline & & \multicolumn{2}{|c|}{ Rata - Rata } & & & & 0,106 & 0,378 \\
\hline & & \multicolumn{2}{|c|}{ Tailing } & & & & & \\
\hline & & $\mathrm{HE}-3(\mathrm{~T})$ & 1 & 0 & 0,208 & 0,548 & 0 & 0,380 \\
\hline & & HE - 6(T) & 2 & 0,060 & 0,099 & 0,548 & 0,606 & 0,181 \\
\hline & & HE - 9(T) & 3 & 0 & 0,218 & 0,548 & 0 & 0,398 \\
\hline & & Rat & Rata & & & & 0,202 & 0,319 \\
\hline \multirow{10}{*}{3.} & \multirow{10}{*}{$\begin{array}{c}\text { Lidah } \\
\text { Mertua }\end{array}$} & \multicolumn{2}{|c|}{ Campuran } & & & & & \\
\hline & & $L M-2(C)$ & 1 & 0,069 & 0,210 & 0,387 & 0,329 & 0,543 \\
\hline & & LM - 5(C) & 2 & 0,020 & 0,188 & 0,387 & 0,106 & 0,486 \\
\hline & & $\mathrm{LM}-8(\mathrm{C})$ & 3 & 0,040 & 0,139 & 0,387 & 0,288 & 0,359 \\
\hline & & \multicolumn{2}{|c|}{ Rata - Rata } & & & & 0,241 & 0,463 \\
\hline & & \multicolumn{2}{|c|}{ Tailing } & & & & & \\
\hline & & $L M-3(T)$ & 1 & 0 & 0,190 & 0,548 & 0 & 0,347 \\
\hline & & $L M-6(T)$ & 2 & 0,060 & 0,259 & 0,548 & 0,232 & 0,473 \\
\hline & & LM - 9(T) & 3 & 0,050 & 0,209 & 0,548 & 0,239 & 0,381 \\
\hline & & \multicolumn{2}{|c|}{ Rata - Rata } & & & & 0,157 & 0,400 \\
\hline
\end{tabular}

Sumber : Hasil Analisis Laboratorium BARISTAN dan analisis perhitungan, 2015 
Berdasarkan Tabel 6. hasil analisis perhitungan nilai BCF masing - masing pada setiap jenis tanaman yaitu tanaman hanjuang (Cordyline fruicosa), tanaman helikonia (Heliconia psittacorum) dan tanaman lidah mertua (Sansevieria trifasciata) di media campuran sebesar 0,$290 ; 0,378 ; 0,463$ dan media tailing sebesar 0,$235 ; 0,319 ; 0,400$. Nilai tersebut berada pada rentang $0,1-1$ yang menunjukkan ketiga jenis tanaman hias bersifat akumulator sedang dalam penyerapan logam merkuri $(\mathrm{Hg})$. Pada media kontrol nilai BCF tidak dapat dihitung karena media tanah tersebut tidak memiliki kandungan merkuri atau bernilai 0 .

Nilai TF yang dihasilkan pada media campuran yaitu $0 ; 0,106 ; 0,241$ dan media tailing yaitu 0,$051 ; 0,202 ; 0,157$. Berdasarkan hasil tersebut, nilai TF lebih kecil daripada 1 (<1) yang menunjukkan translokasi internal merkuri lebih besar ke bagian akar tanaman dibandingkan dengan bagian tajuk tanaman atau sebaliknya sehingga mekanisme atau proses yang terjadi pada penyerapan logam $\mathrm{Hg}$ dari tanaman hias hanjuang (Cordyline fruicosa), helikonia (Heliconia psittacorum) dan lidah mertua (Sansevieria trifasciata) adalah fitostabilisasi.

\section{Kesimpulan}

1. Efisiensi penyerapan merkuri $(\mathrm{Hg})$ yang terbaik terjadi di media tailing pada tanaman lidah mertua (Sansevieria trifasciata) memiliki efisiensi tertinggi sebesar $46,72 \%$ dengan konsentrasi $0,548 \mathrm{mg} / \mathrm{kg}$ dan media campuran memiliki efisiensi sebesar $57,36 \%$ dengan konsentrasi $0,378 \mathrm{mg} / \mathrm{kg}$. Sedangkan efisiensi penyerapan terendah oleh tanaman hanjuang (Cordyline fruicosa) di media tailing sebesar $25,30 \%$ dengan konsentrasi merkuri yaitu $0,548 \mathrm{mg} / \mathrm{kg}$ dan media campuran memiliki efisiensi sebesar 29,30\% dengan konsentrasi 0,378 mg/kg.

2. Nilai bioconcentration factor (BCF) dari tanaman hanjuang (Cordyline fruicosa), helikonia (Heliconia psittacorum) dan lidah mertua (Sansevieria trifasciata) di media campuran sebesar 0,$290 ; 0,378 ; 0,463$ dan media tailing sebesar 0,235; 0,$319 ; 0,400$. Sedangkan nilai translocation factor (TF) dari tanaman hanjuang (Cordyline fruicosa), helikonia (Heliconia psittacorum) dan lidah mertua (Sansevieria trifasciata) di media campuran sebesar $0 ; 0,106 ; 0,241$ dan media tailing sebesar 0,$051 ; 0,202 ; 0,157$.

\section{UCAPAN TERIMAKASIH}

Dengan selesainya penelitian ini saya mengucapkan terima kasih yang sebesar-besarnya kepada Allah Swt, kedua orang tua, kedua dosen pembimbing yaitu Ibu Isna Apriani, S.T, M.Si dan Ibu Sarma Slahaan, S.Si, M.Si serta kepada teman-teman Teknik Lingkungan 2011 dan semua orang yang telah berperan dalam membantu penelitian yang tidak dapat di ucapkan satu persatu. Harapan saya penelitian ini dapat bermanfaat bagi semua dan dapat dipergunakan sebagaimana mestinya.

\section{DAFTAR PUSTAKA}

Alloway, B.J and D.C Ayres. 1995. Chemical Principle of Environmental Pollution, $2^{\text {nd }}$ Edition, Blackie Academic and Professional, Chapman \& Hall, London-WenheimNew York. Tokyo-Melbourne-Madras.

Dinas Pertambangan dan Energi Provinsi Kalimantan Barat. 2014. Sumberdaya/ Potensi Bahan Mineral Galian Emas Kalimantan Barat. 
Ghosh, M and Singh, S. P. 2013. Comparative uptake and phytoextraction study of soil induced chromium by accumulator and high biomass weed spesies. Journal Applied Ecology and Environmental Research vol 3 page 67-69.

Hardjowigeno, S. 1995. Ilmu Tanah. Akademika pressindo. Jakarta.

Haryanti, D., Budianta. D, dan Salni.2013. Potensi Beberapa Jenis Tanaman Hias sebagai Fitoremediasi Logam Timbal $(\mathrm{Pb})$ dalam Tanah. Program Studi Pengelolaan Lingkungan. Universitas Sriwijaya.

Haque, N., J.R. Peralta-Videa, G.L. Jones, T.E. Gill, and J.L. Gardea-Torresdey. 2008. Screening the phytoremediation potential of desert broom (Baccharis Sarothroides Gray) growing on mine tailings in Arizona, USA. Environmental Pollution. 153:362368. Dikutip oleh Novandi R. 2014.

Mirdat, Patadungan, Yosep T., dan Isrun. 2013. Status Logam Berat Merkuri (Hg) Dalam Tanah Pada Kawasan Pengolahan Tambang Emas Di Kelurahan Poboya, Kota Palu. Program Studi Agroteknologi Fakultas Pertanian. Palu : Universitas Tadulako.

Soepardi, G. 1983. Sifat dan Ciri Tanah. Departemen Ilmu-IImu Tanah. Fakultas Pertanian. Institut Pertanian Bogor. Bogor.

Standar Nasional Indonesia 06 - 6992.2 - 2004. Sedimen-Bagian 2 : Cara uji merkuri (Hg) secara uap dingin (cold vapour) dengan mercury analyzer. Badan Standardisasi Nasional 2015. Jakarta Pusat 10340. Indonesia.

Stevenson, F.J. 1982. Humus Chemistry: Genesis, Composition, Raction. John Willey, New York. 